\title{
Predictive Modeling and Validation on Growth, Production of Asexual Spores and Ochratoxin A of Aspergillus Ochraceus Group under Abiotic Climatic Variables
}

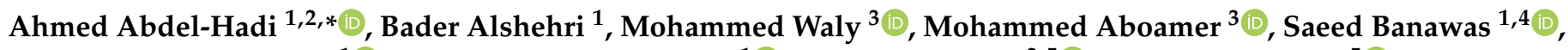 \\ Mohammed Alaidarous ${ }^{1}\left(\mathbb{D}\right.$, Manikandan Palanisamy ${ }^{1}\left(\mathbb{D}\right.$, Mohamed Awad ${ }^{2,5}{ }^{(\mathbb{D}}$ and Alaa Baazeem ${ }^{5}(\mathbb{D})$ \\ 1 Department of Medical Laboratory Sciences, College of Applied Medical Sciences, Majmaah University, \\ Majmaah 11952, Saudi Arabia; b.alshehri@mu.edu.sa (B.A.); s.banawas@mu.edu.sa (S.B.); \\ m.alaidarous@mu.edu.sa (M.A.); m.palanisamy@mu.edu.sa (M.P.) \\ 2 Department of Botany and Microbiology, Faculty of Science, Al-Azhar University, \\ Assuit Branch, Assuit 71524, Egypt; m.fadl@tu.edu.sa \\ 3 Department of Medical Equipment Technology, College of Applied Medical Sciences, Majmaah University, \\ Majmaah 11952, Saudi Arabia; m.waly@mu.edu.sa (M.W.); m.aboamer@mu.edu.sa (M.A.) \\ 4 Department of Biomedical Sciences, Oregon State University, Corvallis, OR 97331, USA \\ 5 Department of Biology, College of Science, Taif University, P.O. Box 11099, Taif 21944, Saudi Arabia; \\ aabaazeem@tu.edu.sa \\ check for \\ * Correspondence: a.abdelhadi@mu.edu.sa
} updates

Citation: Abdel-Hadi, A.; Alshehri, B.; Waly, M.; Aboamer, M.; Banawas, S.; Alaidarous, M.; Palanisamy, M.; Awad, M.; Baazeem, A. Predictive Modeling and Validation on Growth, Production of Asexual Spores and Ochratoxin A of Aspergillus Ochraceus Group under Abiotic Climatic Variables. Microorganisms 2021, 9 , 1321. https://doi.org/10.3390/ microorganisms 9061321

Academic Editor: J. H. (Han) de Winde

Received: 21 April 2021

Accepted: 11 June 2021

Published: 17 June 2021

Publisher's Note: MDPI stays neutral with regard to jurisdictional claims in published maps and institutional affiliations.

Copyright: (c) 2021 by the authors. Licensee MDPI, Basel, Switzerland. This article is an open access article distributed under the terms and conditions of the Creative Commons Attribution (CC BY) license (https:// creativecommons.org/licenses/by/ $4.0 /)$.

\begin{abstract}
This study aimed to generate predictive models for growth, sporulation, and ochratoxin A (OTA) production under abiotic climatic variables, including temperatures $\left(15-35^{\circ} \mathrm{C}\right)$ and water activity levels (0.99-0.90 $\mathrm{a}_{\mathrm{W}}$ ) by Aspergillus ochraceus group. The data were divided into three sets: one for training, one for testing, and the third one for model validation. Optimum growth occurred at $0.95 \mathrm{a}_{\mathrm{w}}$ and $25^{\circ} \mathrm{C}$ and $0.95 \mathrm{a}_{\mathrm{w}}$ and $30^{\circ} \mathrm{C}$ for A. westerdijkiae and A. steynii, respectively. Significantly improved $A$. westerdijkiae and $A$. steynii spore production occurred at $0.95 \mathrm{a}_{\mathrm{w}}$ and $20^{\circ} \mathrm{C}$ and $0.90 \mathrm{a}_{\mathrm{w}}$ and $35{ }^{\circ} \mathrm{C}$, respectively. A. steynii and $A$. westerdijkiae produced the majority of OTA at $35{ }^{\circ} \mathrm{C}$ and $0.95 \mathrm{a}_{\mathrm{w}}$ and $25-30{ }^{\circ} \mathrm{C}$ at $0.95-0.99 \mathrm{a}_{\mathrm{w}}$, respectively. The accuracy of the third-order polynomial regression model reached $96 \%$ in growth cases, $94.7 \%$ in sporulation cases, and $90.9 \%$ in OTA production cases; the regression coefficients (R2) ranged from 0.8819 to 0.9978 for the Aspergillus ochraceus group. A reliable agreement was reached between the predicted and observed growth, sporulation, and OTA production. The effects of abiotic climatic variables on growth, sporulation, and OTA production of $A$. ochraceus group have been effectively defined, and the models generated were responsible for adequately predicted and validated models against data from other strains within A. ochraceus group that had been published in the literature under the current treatments. These models could be successfully implemented to predict fungal growth and OTA contamination on food matrices for these strains under these conditions.
\end{abstract}

Keywords: Aspergillus westerdijkiae; Aspergillus steynii; water activity; temperature; growth rate; sporulation; ochratoxin A; polynomial regression

\section{Introduction}

Ochratoxin A (OTA) is one of the most important mycotoxins that can create a very wide range of health problems, such as nephrotoxic, immunotoxic, and teratogenic effects, in animals and humans (IARC 1993). Ochratoxin A can contaminate a wide range of foods, such as grains, cereal products, coffee, grapes, grape- products, dried fruits, nuts, cocoa, spices, and chocolate [1-3]. Ochratoxin A is predominantly produced by the genus Aspergillus. Two new ochratoxigenic species called A. westerdijkiae and A. steynii were separated from the Aspergillus section Circumdati that is more frequently described as the A. ochraceus species responsible for ochratoxins contamination in a wide variety of food 
products [4]. Consequently, since this differentiation has been demonstrated, there are several studies in which $A$. westerdijkiae, which is mainly responsible for OTA contamination, is isolated from a number of fresh materials, particularly coffee [5-7], grapes [8], paprika [9], barley [10], meat products [11]. It has been reported that A. steynii is the major OTA-producer within the section, with approximately $90 \%$ of the strains and toxins producing 1000 times more OTA than A. ochraceus, followed by $A$. westerdijkiae with $75 \%$ of its strains producing OTA and levels of production 100 times greater than A. ochraceus [12].

Previously, studies have investigated the ecology of species $A$. ochraceus. The single effect and interactions between water activity and temperature on growth, sporulation, OTA, and OTB of A. ochraceus, A. steynii, and A. westerdijkiae were investigated [13]. It has been shown that the growth of $A$. steynii and $A$. westerdijkiae was strongly affected by an increase in water activity and temperature, and neither growth nor sporulation resulted in good OTA production indicators for A. steynii or A. westerdijkiae [14]. Recent studies have been conducted with Aspergillus section Circumdati (A. westerdijkiae, A. ochraceus, A. steynii) and section Nigri species (A. carbonarius) in vitro and on stored coffee beans in relation to OTA production under climate change conditions [15,16]. Currently, a significant interest has been expressed in the impact of abiotic climatic variables (temperature, water availability, and $\mathrm{CO}_{2}$ ) and their interactions on the colonization of economically significant commodities with mycotoxic fungi and mycotoxins [17-20].

Mathematical models have been a powerful method for explaining microbial responses to diverse environmental conditions [21]. Predictive modeling of fungal species is still not given the same significance as bacterial growth models because of complexities in the estimation of fungal development and the collection of sufficient, appropriate, and reproducible data [22]. There are three types of microbial kinetic models: primary, secondary, and tertiary [23]. Primary models represent the changes in number of microorganisms in a population over time under certain conditions [24]. Secondary models explain the influence of environmental factors, such as water activity and temperature, on key parameters of the primary model. Tertiary models integrate primary and secondary models with a computer system to provide a comprehensive prediction tool [24]. In predictive microbiology, polynomial models have been successfully utilized to quantify the impacts of several environmental parameters on fungal growth, most notably $\mathrm{a}_{\mathrm{w}}$, temperature, and $\mathrm{pH}$. They are commonly constructed using multiple linear regression analyses and allow for the assessment of environmental parameters and their interactions [22]. A significant amount of information on models is now available to predict fungal growth and development of mycotoxins in food matrices [25-27]. The lack of validity of the tested models was a disadvantage for the developed models. Practically, no reliable data were available for developing models to predict and validate sporulation and OTA production in the $A$. ochraceus group. Thus, the aims of this work were (a) to generate predictive models for the combined effect of temperature and water activity $\left(\mathrm{a}_{\mathrm{w}}\right)$ on growth, spore production, and OTA production of $A$. westerdijkiae and A. steynii and (b) to validate the generated models against published data from other strains within the same genus in the literature.

\section{Materials and Methods}

\subsection{Fungal Strains}

Two ochratoxigenic strains very similar in morphology (colony and microscopic characteristics), but with variations in their responses to environmental conditions in terms of OTA biosynthesis regulation [28] from the group of A. ochraceus within section Circumdat $i$ (A. steynii IBT 23096, and A. westerdijkiae IBT 23971) were used in the experimental work of this study. Prof. J. Frisvad (Tech. Univ. of Denmark, Lyngby, Denmark) kindly supplied the strains [4].

\subsection{Media Preparations}

The water activity levels of yeast extract sucrose (YES) medium, which is a toxininduced medium (20.0 $\mathrm{g} \mathrm{L}^{-1}$ yeast extract, $150.0 \mathrm{~g} \mathrm{~L}^{-1}$ sucrose, $15 \mathrm{~g} \mathrm{~L}^{-1}$ agar), was modified 
with glycerol to three levels $\left(0.99,0.95\right.$, and $\left.0.90 \mathrm{a}_{\mathrm{w}}\right)$. Known quantities of glycerol/water solutions ( $51 \mathrm{~g} \mathrm{~L}^{-1}$ in case of $0.99 \mathrm{a}_{\mathrm{w}}, 231.5 \mathrm{~g} \mathrm{~L}^{-1}$ in $0.95 \mathrm{aw}$, and $378.9 \mathrm{~g} \mathrm{~L}^{-1} 0.90 \mathrm{a}_{\mathrm{w}}$ ) at these aw levels were prepared and applied to the medium [29]. Media were autoclaved at $121^{\circ} \mathrm{C}$ for $20 \mathrm{~min}$. The same treatments were placed in separate polyethylene bags and confirmed using AQUALAB ${ }^{\circledR} 3 T E$, USA, for verification of actual values.

\subsection{Culturing and Growth Rate Assessment}

Petri plates with modified media were inoculated with $5 \mu \mathrm{L}$ of $10^{6}$ spore suspension of both strains and incubated at $15,20,25,30$, and $35^{\circ} \mathrm{C}$. Three replicates were conducted for all studies. Those at the same level of water activity were placed in sealed polyethylene bags. The diameters of the growing colony of replicated plates were measured in two directions at right angles with each other. Colony growth measurements were recorded daily for 10 days until the colonization of the Petri plates was completed in some treatments [30]. The same plates used for growth measurements were used for OTA determinations. The growth rate was determined by plotting the radial mycelium growth across time and using the slope of the linear growth process to obtain the radial growth rate (mm/day) [31].

\subsection{Measurements of Asexual Spores}

The species were inoculated on YES medium covered with cellophane $(8.5 \mathrm{~cm}, \mathrm{P} 400$, Cannings Ltd., Bristol, UK), allowing the whole mycelium of the colony to be separated. The entire mycelium was suspended in sterile water $(10 \mathrm{~mL})$ containing a wetting agent (Tween $80,0.1 \%$ ) to wet the spores after 10 days of incubation. Three replicates were conducted for all treatments. Spores were filtered through sterile glass wool, and the filtrate was centrifuged to produce a spore pellet. The number of spores per $\mathrm{cm}$ of the colony at the end of the incubation time was determined using a hemocytometer and a binocular Olympus Microscope connected with a camera and LCD screen [13].

\subsection{Estimation of Ochratoxin A}

Three plugs ( $3 \mathrm{~mm}$ in diameter) were taken out from the agar of each replicate across the colony surface, with one in the center and two on both sides using a cork borer. The plugs were put into $2 \mathrm{~mL}$ Eppendorf tubes and weighed. OTA was extracted by adding $1 \mathrm{~mL}$ of HPLC grade methanol and shaking for 1 hour. The mycelial residue was removed using centrifugation. The extracts were directly derived into amber HPLC vials. Samples were collected and analyzed using HPLC with a 470-fluorescence detector (Agilent, USA) ( $\lambda$ exc $333 \mathrm{~nm}, \lambda$ em $460 \mathrm{~nm}$ ) and a C 18 column (Luna Spherisorb ODS2 $150 \times 4.6 \mathrm{~mm}$, $5 \mu \mathrm{m}$ ) operated using Waters Millennium 32 software. The analysis was performed at a flow rate $1 \mathrm{~mL} \mathrm{~min}{ }^{-1}$ with a mobile phase of $41 \%$ water: $57 \%$ acetonitrile: $2 \%$ acetic acid with a run time of $15 \mathrm{~min}$ with a detection limit of $0.5 \mathrm{ng} \mathrm{g}^{-1}$ and quantification limit of $2.4 \mathrm{ng} \mathrm{g}^{-1}[13,18]$.

\subsection{Modeling of Fungal Growth, Sporulation, and Ochratoxin A}

The data were divided into three sets. The data produced from the experimental work with Aspergillus westerdijkiae IBT 23971 were used for the training set, the data produced from the experimental work with Aspergillus steynii IBT 23096 were used for the testing and derived data from Aspergillus ochraceus IBT 11952, Aspergillus steynii IBT 22339, and Aspergillus westerdijkiae IBT 10738 [13] were used to validate the models. To generate a model capable of predicting fungal growth rate, sporulation, and OTA production as a function of $\mathrm{a}_{\mathrm{w}}$ and temperature, the following processes were applied using Microsoft Excel software and MATLAB2018a [32,33]. 


\subsubsection{Normalization}

The growth, sporulation, and OTA production data from Aspergillus westerdijkia at $\mathrm{a}_{\mathrm{w}}$ $(0.95)$ and temperatures $\left(20,25,30,35^{\circ} \mathrm{C}\right)$ were normalized with the general expression:

$$
X^{\prime}=\frac{X-X_{\min }}{X_{\max }-X_{\min }}
$$

where $X_{\min }$ is the minimum value of input variables (growth, sporulation, and ochratoxin A), $X_{\max }$ is the maximum value of the input variables, and $X^{\prime}$ is the normalized calculated value.

\subsubsection{Linear Interpolation}

The data of growth, sporulation, and OTA production of $A$. westerdijkiae were interpolated using the linear interpolation formula

$$
y=y_{0}+\left(x-x_{0}\right) \frac{y_{1}-y_{0}}{x_{1}-x_{0}}
$$

In the equation $y$ is the variables data (growth, sporulation, and OTA), $y_{0}$ and $y_{1}$ are the two closest approximations to $y, x$ is temperature data, and $x_{0}$ and $x_{1}$ are the two closest approximations to $x$.

\subsubsection{Polynomial Regression}

A third-order polynomial response surface model (Equation (3)) was fitted to the dependent variables (growth rate, sporulation, and OTA) with the independent variables (temperature), at a fixed $\mathrm{a}_{\mathrm{w}}(0.95)$ :

$$
y=a_{0}+a_{1} x+a_{2} x^{2}+a_{3} x^{3}+\cdots+\varepsilon
$$

In the equation $a_{0} \ldots a$ represent the estimated regression coefficients, $\varepsilon$ is an unobserved random error with mean zero conditioned on a scalar variable $x$ (temperature), and $y=\lambda$ or $\mu$. In all-purpose, the expected value of $y$ as an nth degree polynomial, yielding the general polynomial regression model. Polynomial regression was used to study the behavior for each type of the Aspergillus ochraceus group.

\subsubsection{Nonlinear Regression}

The effect of temperature on the growth rate, sporulation, and OTA production was predicted using the nonlinear regression equation:

$$
\ln (y)=\ln (a)+b x+u
$$

In the equation, $a$ and $b$ are the parameters, and $u$ is the multiplicative error, suggesting the estimation of the unknown parameters by linear regression of $\ln (y)$ on $x$.

\subsection{Model Testing and Validation}

The developed models from A. westerdijkiae IBT 23971 data were tested on A. steynii IBT 23096 data and validated against external data from Abdel-Hadi and Magan [13] for Aspergillus westerdijkiae 10738, Aspergillus steynii 22339, and Aspergillus ochraceus 11952 using the same temperatures employed for the model and $\mathrm{a}_{\mathrm{w}}$ level (0.95). Performances of the generated models were evaluated using the mean squared error (MSE) and the root mean squared error (RMSE), as suggested by Ross [34], where the RMSE value near zero indicates a better model fit:

$$
R M S E=\sqrt{\frac{1}{N} \sum_{i=1}^{N}\left(M_{i}-A_{i}\right)^{2}}
$$


where: $R M S E=$ root mean square error, $N=$ sample size, $M_{i}=$ predicted values, and $A_{i}=$ observed values.

\subsection{Statistical Analysis}

All experiments for growth, sporulation, and ochratoxin A production were conducted and repeated with three replicates for measurements of asexual spores and three replicates for growth measurements and OTA estimations. Statistical analyses were performed using Statistica, version 8 for two-way ANOVA, followed by Fisher's LSD test to compare the means for all treatments that were significantly different at $p<0.05$.

\section{Results and Discussion}

\subsection{Growth Assessment in Relation to Abiotic Climatic Variables}

Figure 1 shows growth rate results for A. steynii 23096 and A. westerdijkiae 23971 at varying $\mathrm{a}_{\mathrm{w}}$ and temperature levels. The optimum growth for both species was around $0.95 \mathrm{a}_{\mathrm{w}}$, but it occurred at different temperatures. Optimal growth occurred at $25^{\circ} \mathrm{C}$ for A. westerdijkiae 23971 , and at $30^{\circ} \mathrm{C}$ for $A$. steynii 23096 . Generally, both species exhibited similar growth rates at $0.90 \mathrm{a}_{\mathrm{w}}$. Aspergillus steynii 22339 grew faster than A. westerdijkiae 23971 at higher water activity ( 0.95 and 0.99$)$. There was no growth for both strains at $15^{\circ} \mathrm{C}$ with 0.90 and $0.95 \mathrm{a}_{\mathrm{w}}$. Statistical analysis of the data-sets demonstrated that single and interacting factors were all significant for $\mathrm{a}_{\mathrm{w}}$, temperature treatments, and their interactions (Table 1). A previous study showed that $A$. steynii and $A$. westerdijkiae growth rates were significantly reduced at lower $\mathrm{a}_{\mathrm{w}}$ values (0.91 and 0.93) and reached the optimum at $\mathrm{a}_{\mathrm{w}}=0.97$ when they grew in medium green coffee [5]. A further study examined the effect of ecophysiological factors on growth, sporulation, and OTA development of $A$. steynii and A. westerdijkiae in CYA medium (Czapek Yeast Agar) and food products media. The authors found similar permissive and optimum growth conditions for $A$. steynii and $A$. westerdijkiae, where the growth increased with temperature in both species, and fungal growth was significantly reduced at the lowest $\mathrm{a}_{\mathrm{w}}$ [14]. Similarly, the optimum growth of $A$. westerdijkiae was usually at $\mathrm{a}_{\mathrm{w}}$ rates between 0.93 and 0.97 , and it was significantly reduced at all temperatures measured in medium dry-cured ham with lower $\mathrm{a}_{\mathrm{w}}$ [11]. Another study examined the influence of temperature and $\mathrm{a}_{\mathrm{w}}$ on $A$. westerdijkiae growth in stored barley, and the study suggested that $\mathrm{a}_{\mathrm{w}}$ is a critical factor for fungal growth in this product [35]. The European Commission suggests that changes in Mediterranean zones may shift to a temperature increase of $4-5{ }^{\circ} \mathrm{C}$ associated with prolonged dry seasons [36]. High temperatures reaching $30^{\circ} \mathrm{C}$ and water stress conditions $\left(0.95 \mathrm{a}_{\mathrm{w}}\right)$ affected A. steynii and $A$. westerdijkiae growth positively, while low temperature $\left(20^{\circ} \mathrm{C}\right.$ or less) and high drought $\left(0.90 \mathrm{a}_{\mathrm{w}}\right)$, negatively. Regarding this, Akbar et al. [16] suggested that lag phases prior to growth and growth rates of A. westerdijkiae, Aspergillus steynii grown on coffeebased media and stored coffee beans were significantly influenced by climate change (CC) factors, and these strains tended to become more tolerant of elevated temperature. A recent study by Akbar et al. [18] reported that $A$. westerdijkiae strains could colonize rapidly on drying green coffee in a range of $25-35{ }^{\circ} \mathrm{C}$ with reduced growth at $0.90 \mathrm{a}_{\mathrm{w}}$.

\subsection{Sporulation Assessment in Relation to Abiotic Climatic Variables}

There were substantial differences between $A$. steynii and $A$. westerdijkiae at all the temperatures tested, with no spores produced at $0.99 \mathrm{a}_{\mathrm{w}}$. Spore production was significantly enhanced in A. westerdijkiae 23971 at $0.95 \mathrm{a}_{\mathrm{w}}$ and $20^{\circ} \mathrm{C}$, and A. steynii 23096 had remarkably increased sporulation ability at $0.90 \mathrm{a}_{\mathrm{w}}$ and $35^{\circ} \mathrm{C}$ (Figure 2). Water activity had a significant effect on sporulation in both species, where they displayed dramatic growth responses, with slower mycelium growth and higher spore production when water stress was imposed but at different temperatures. The effect of single and two-way interactions is shown in Table 1 . There were statistically significant differences due to the single, interacting factors of $\mathrm{a}_{\mathrm{w}}$ and temperature in species. Many studies have been reported in the literature regarding asexual spore production of various mycotoxigenic fungi, such as A. flavus, 
A. ochraceus group, A. niger, and Fusarium verticillioides, on synthetic media and food matrix [37-39]. Results similar to our study were obtained by one research group [11] with Penicillium nordicum and A. westerdijkiae sporulation grown on a dry-cured ham-based medium. The authors reported that the highest number of spores for $P$. nordicum and A. westerdijkiae Type-strain spores were produced at 0.97 aw and $20{ }^{\circ} \mathrm{C}$, and $0.90 \mathrm{a}_{\mathrm{w}}$ and $30{ }^{\circ} \mathrm{C}$, respectively. There was a difference in the number of spores produced at $0.90 \mathrm{a}_{\mathrm{w}}$ and $30^{\circ} \mathrm{C}$ compared to our study. This may because the incubation time was longer. In contrast, other studies reported that $A$. steynii, and $A$. westerdijkiae on food product-based media and $A$. flavus grown on maize stalks substrates showed abundant sporulation at $0.99 \mathrm{a}_{\mathrm{w}}[16,40]$. This may explain the effect of substrate or strain type on spore production. Zhang et al. [41] studied the activity of $A$. flavus and the transcriptome at 0.99 and $0.93 \mathrm{a}_{\mathrm{w}}$ and $28{ }^{\circ} \mathrm{C}$ grown on a conducive YES medium. They reported that both conidiation and AFB1 biosynthesis decreased at $0.93 \mathrm{a}_{\mathrm{w}}$ when compared to $0.99 \mathrm{a}_{\mathrm{w}}$ due to the upregulation of 3156 genes and downregulation of 2206 genes identified between 0.99 and $0.93 \mathrm{a}_{\mathrm{w}}$ treatments. They suggested that $A$. flavus underwent an extensive transcriptome response during the variation in water activity levels.

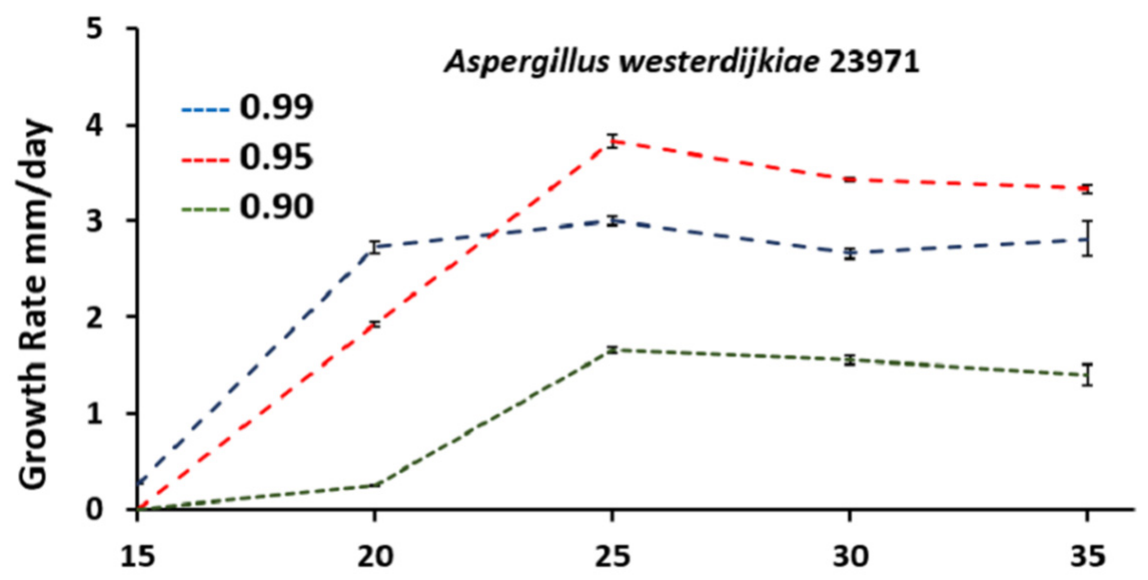

Aspergillus steynii 23096

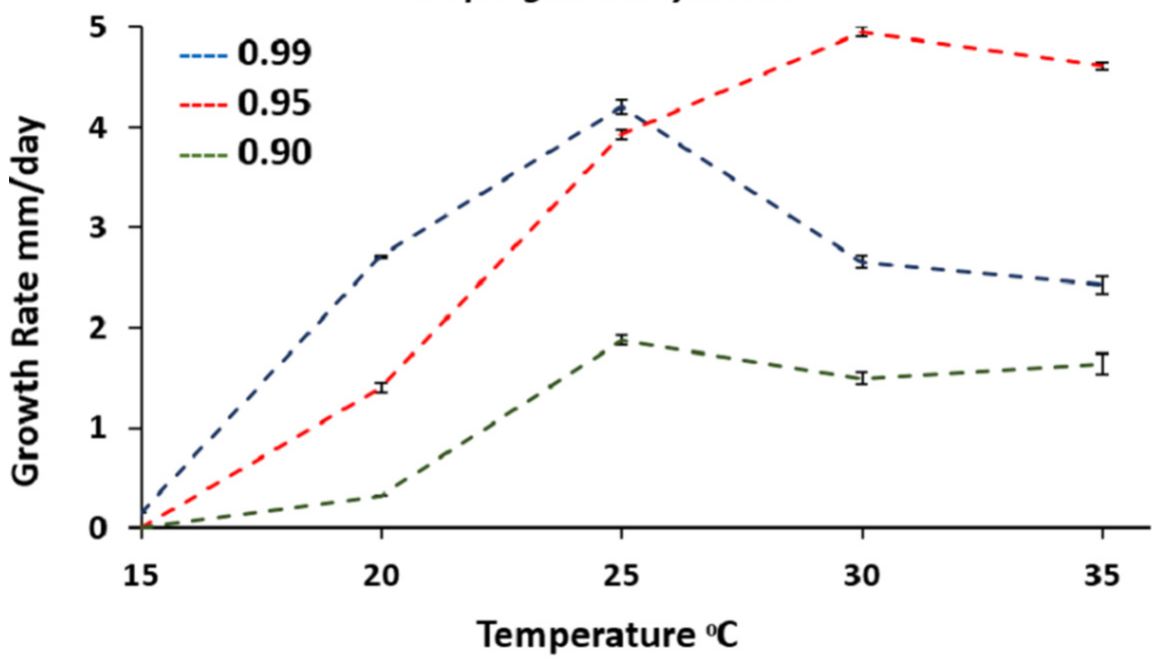

Figure 1. A. westerdijkiae IBT 23971 and A. steynii IBT 23096 growth rate in relation to temperature and water activity $\left(\mathrm{a}_{\mathrm{w}}\right)$ in the YES medium. Vertical bars show standard errors for all strains. 
Table 1. Variance analysis of the influence of temperature, $\mathrm{a}_{\mathrm{w}}$ and their interaction on growth rate, spore production, and ochratoxin A production of A. westerdijkiae and A. steynii.

\begin{tabular}{|c|c|c|c|c|c|c|c|c|c|}
\hline & \multirow[b]{2}{*}{ Factor } & \multicolumn{4}{|c|}{ Aspergillus Westerdijkiae 23971} & \multicolumn{4}{|c|}{ Aspergillus Steynii 23096} \\
\hline & & DF & MS & $\mathbf{F}$ & $\mathbf{P}$ & DF & MS & $\mathbf{F}$ & $\mathbf{P}$ \\
\hline \multirow[t]{3}{*}{ Growth rate } & Temperature & 4 & 11.2329 & 2693.48 & 0.00 & 4 & 17.0717 & 6257.19 & 0.00 \\
\hline & $\mathrm{a}_{\mathrm{W}}$ & 2 & 10.2443 & 2456.42 & 0.00 & 2 & 14.5386 & 5328.76 & 0.00 \\
\hline & Temperature $\times \mathrm{a}_{\mathrm{w}}$ & 8 & 0.9489 & 225.61 & 0.00 & 8 & 2.7519 & 1008.65 & 0.00 \\
\hline \multirow[t]{3}{*}{ Sporulation } & Temperature & 3 & $3.420 \times 10^{13}$ & 3.0773 & 0.046 & 3 & $5.988 \times 10^{13}$ & 137.093 & 0.00 \\
\hline & $\mathrm{a}_{\mathrm{w}}$ & 2 & $1.438 \times 10^{14}$ & 12.9402 & 0.00 & 2 & $1.145 \times 10^{14}$ & 262.299 & 0.00 \\
\hline & Temperature $\times \mathrm{a}_{\mathrm{w}}$ & 6 & $3.632 \times 10^{13}$ & 3.26787 & 0.017 & 6 & $5.654 \times 10^{13}$ & 129.375 & 0.00 \\
\hline \multirow[t]{3}{*}{ Ochratoxin A } & Temperature & 3 & 108.844 & 368.25 & 0.00 & 3 & 96.501 & 251.404 & 0.00 \\
\hline & $\mathrm{a}_{\mathrm{w}}$ & 2 & 66.608 & 225.35 & 0.00 & 2 & 70.678 & 182.566 & 0.00 \\
\hline & Temperature $\times \mathrm{a}_{\mathrm{w}}$ & 6 & 24.262 & 82.69 & 0.00 & 6 & 8.064 & 21.008 & 0.00 \\
\hline
\end{tabular}

Where DF = Degree of freedom; MS = Mean Square; F = Frequency; $\mathrm{P}=$ Probability.
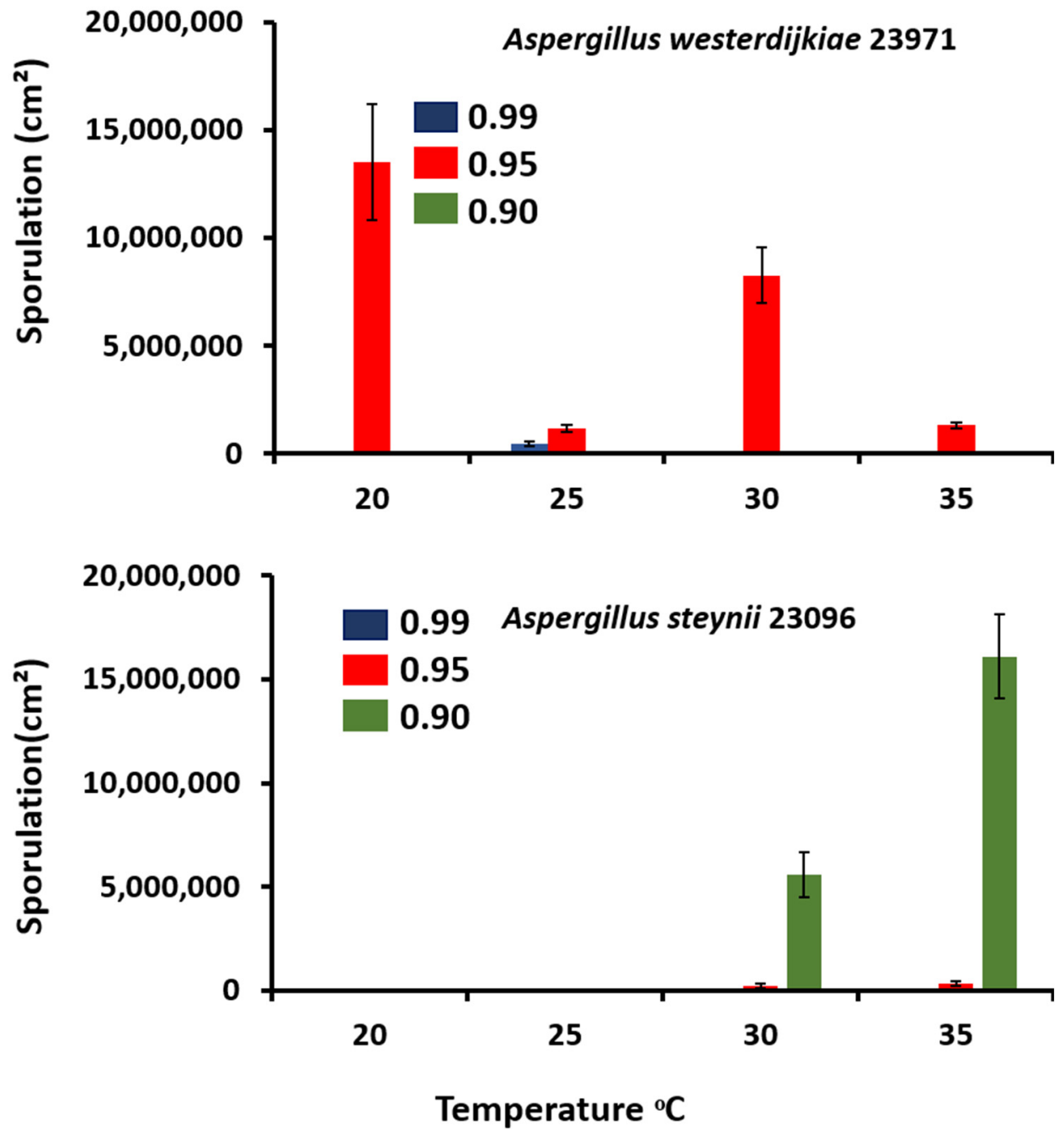

Figure 2. Sporulation of $A$. westerdijkiae IBT 23971 and A. steynii IBT 23096 in relation to temperature and water activity $\left(\mathrm{a}_{\mathrm{w}}\right)$ in the YES medium. Vertical bars show standard errors for all strains.

\subsection{Ochratoxin A Assessment in Relation to Abiotic Climatic Variables}

Figure 3 shows OTA production results of A. westerdijkiae 23971 and A. steynii 23096 under different $\mathrm{a}_{\mathrm{w}}$ and temperature regimes on YES medium. Interestingly, A. westerdijkiae 23971 produced greater amounts of OTA than A. steynii 23096 at all examined tempera- 
tures and $\mathrm{a}_{\mathrm{w}}$ levels. In contrast to this, Gil-Serna et al. [12] reported that A. steynii had the capacity to produce OTA at higher levels than $A$. westerdijkiae. This could be due to genetic diversity and strain specificity and shifts our opinion that A. steynii produces more OTA than A. westerdijkiae. In addition, the increased levels of OTA observed in A. westerdijkiae 23971 could be as YES is a more conducive medium for toxin production for A. westerdijkiae 23971 but not for A. steynii 23096. A. steynii 23096 and A. westerdijkiae 23971 produced the highest amounts of OTA at $35{ }^{\circ} \mathrm{C}$ and $0.95 \mathrm{a}_{\mathrm{w}}$ and at $25-30{ }^{\circ} \mathrm{C}$ and 0.95-0.99 $\mathrm{a}_{\mathrm{w}}$, respectively. Our results are similar to those of another group which reported that $A$. westerdijkiae and $A$. steynii produced most of the OTA at temperatures above $24{ }^{\circ} \mathrm{C}$ and 0.96-0.99 $\mathrm{a}_{\mathrm{w}}$ when grown on food product-based media [16]. In our study, there was a close association between fungal growth and OTA production. Therefore, fungal growth could be used as an indicator of OTA contamination by these strains. In contrast to this, another group reported that there was no significant correlation between fungal growth and OTA production of $A$. westerdijkiae and $A$. steynii grown on food product-based media [16]. Similarly, Gil-Serna et al. [14] stated that neither growth nor sporulation resulted in good OTA production indicators for A. steynii or A. westerdijkiae grown on food matrices-based media. This may be because food-based medium with different carbon sources had a critical impact on the OTA production ability of Aspergillus species. Available information suggests that slightly elevated temperature and interaction with water stress may stimulate OTA produced by fungi and allow new OTA fungal strains to appear in food matrices and become more dominant [15]. Akbar et al. [16] examined the effect of $\mathrm{CC}$ factors and their interactions on OTA production in vitro and on stored coffee beans by $A$. wetserdijkiae, $A$. steynii, $A$. ochraceus, and $A$. carbonarius. They suggested that OTA production stimulated by $A$. westerdijkiae $\left(35^{\circ} \mathrm{C}\right)$ and $A$. niger $\left(30^{\circ} \mathrm{C}\right)$ while reduced by A. carbonarius in stored coffee. This shows the differential ability of OTA producers to adapt to CC factors. A recent study by Lappa et al. [42] examined the effect of temperature and water stress on the expression of genes required for OTA production in A. carbonarius. They showed that, while water activity was the critical factor influencing OTA production, temperature was the only triggering factor to influence the transcription of OTA biosynthesis gene. In addition, an alternative approach is to precede models of anticipated ochratoxins contamination. Cervini et al. [43] reported that the growth of $A$. carbonarius isolated from grapes was relatively unaffected on grape-based media by interacting abiotic $\mathrm{CC}$-related factors (temperature, water availability, and $\mathrm{CO}_{2}$ ), while ochratoxin production was stimulated due to the increase in ochratoxin relative gene expressions. Although several studies have examined the effects of different abiotic climatic factors and their interactions on Aspergillus westerdijkiae, Aspergillus ochraceus, Aspergillus steynii, and Aspergillus niger species/strains $[13,18,37]$, no data on toxin regulation at molecular level and model prediction in vitro and on food matrices are available to date, and this knowledge gap needs to be addressed [44].

\subsection{Predictive Modeling and Validation}

Since $A$. westerdijkiae IBT 23971 produced more OTA under all tested conditions and can produce asexual spores under $0.95 \mathrm{a}_{\mathrm{w}}$ at all temperatures, the data for its growth, sporulation, and OTA production under 0.95 aw was selected to generate the model. Sporulation of $A$. westerdijkiae was possible only at $0.95 \mathrm{a}_{\mathrm{w}}$. Therefore, no data modeling was performed at 0.99 and $0.90 \mathrm{a}_{\mathrm{w}}$ because models, with the exception of no-data, generate a good fit for experimental data [45]. Initially, the colony growth rate, sporulation, and OTA production were modeled and normalized vs. temperature with a normalization formula (Equation (1)). The experimentally observed data of growth rate, sporulation, and OTA production were fitted with rescaled normalized data (Figure 4). A linear interpolation (Equation (2)) method was used to estimate growth rate, sporulation, and OTA production under estimated temperatures (Figure 5). A third-order polynomial equation (3) was used to describe the effect of temperature on the growth rate, sporulation, and OTA production (Figure 6). There was a strong positive correlation between growth rate, sporulation, and 
OTA production of $A$. westerdijkiae IBT 23971 and temperature, with regression coefficients $\left(R^{2}\right)$ of $0.96,0.88$, and 0.977 , for growth rate, sporulation, and OTA production, respectively. The third-polynomial regression model was applied for all the strains where $R^{2}$ ranged from 0.9619 to 0.9797 for growth rate, 0.8819 to 0.9903 for sporulation, and 0.977 to 0.9978 for OTA production (Table 2).

To our knowledge, this is the first study to use third-order polynomial regression models for the prediction of growth, sporulation, and OTA production under different temperatures and $0.95 \mathrm{a}_{\mathrm{w}}$ using Aspergillus ochraceus group data. This study has provided a useful model that can be applied to OTA producers in vitro and validated on stored food that can be contaminated with OTA producers. Garcia et al. [22] reported that the polynomial model is the most common model used to describe fungal growth because of its flexibility and simplicity. They found good prediction ability given by high $R^{2}$ and low RMSE. Aspergillus westerdijkiae IBT 23971 growth, sporulation, and OTA production showed significant differences due to the single and interacting factors of $\mathrm{a}_{\mathrm{w}}$ and temperature (Table 1). Detailed information about sporulation of the Aspergillus ochraceus group is very important to understand fungal colonization. The present study suggests that the change in climate factors can alter the sporulation of these strains in an unpredictable way. The utilization of sporulation data under CC factors will be a significant addition for future studies in developing successful models to understand the fungal contamination in foodstuffs. Previous studies reported that optimal water activity for growth, sporulation, and OTA production for OTA producers is $0.95 \mathrm{a}_{\mathrm{w}}$ for culture media and food matrices [37,39].
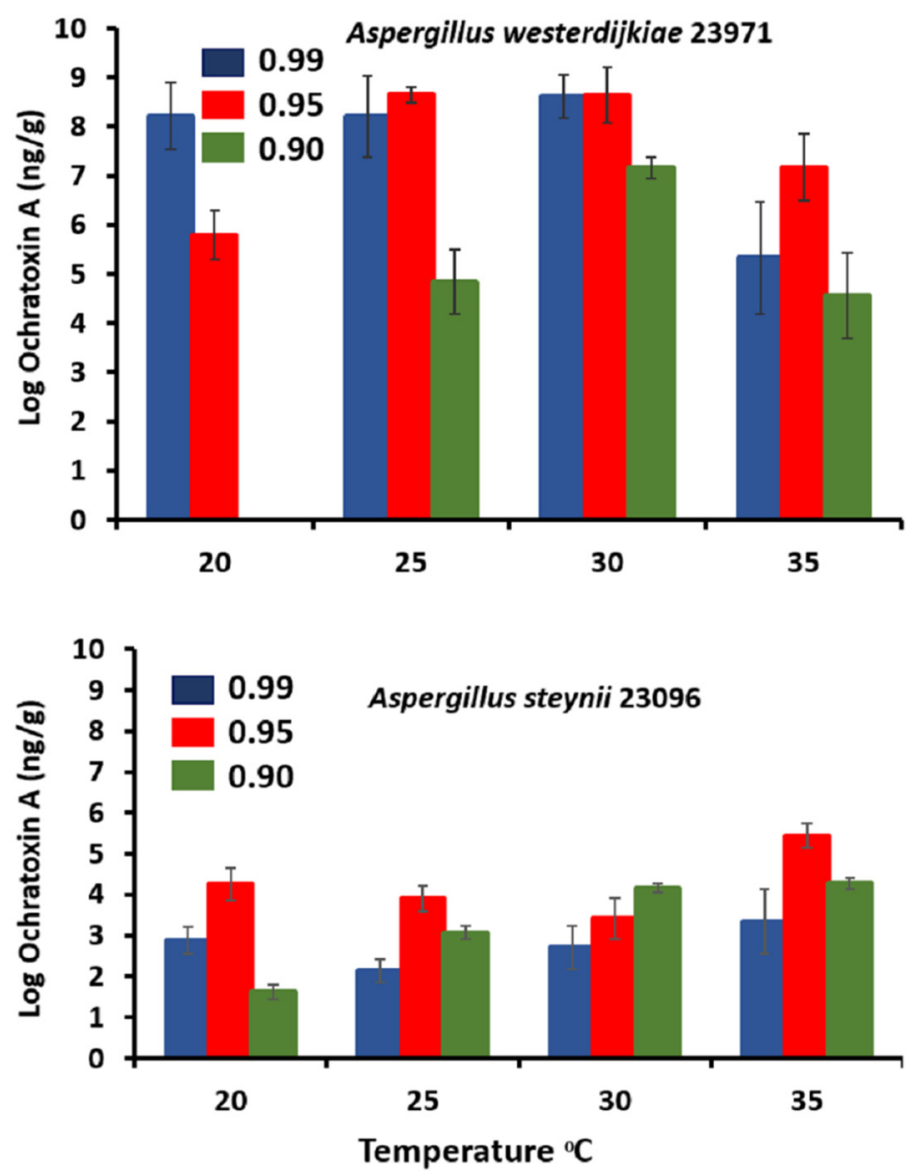

Figure 3. Ochratoxin A of A. westerdijkiae IBT 23971 and A. steynii IBT 23096 in relation to temperature and water activity $\left(\mathrm{a}_{\mathrm{W}}\right)$ in the YES medium. Vertical bars show standard errors for all strains. 


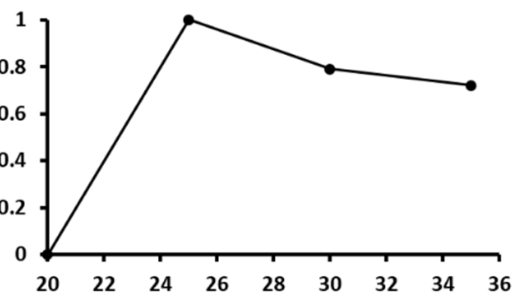

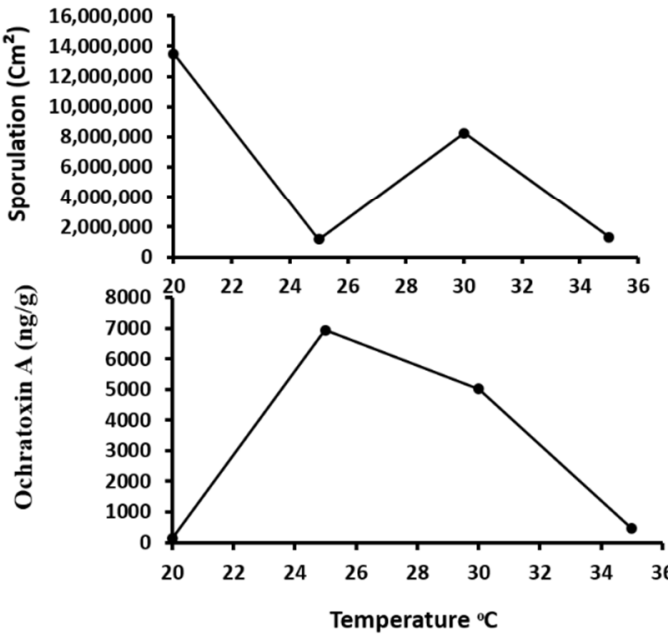

(a)
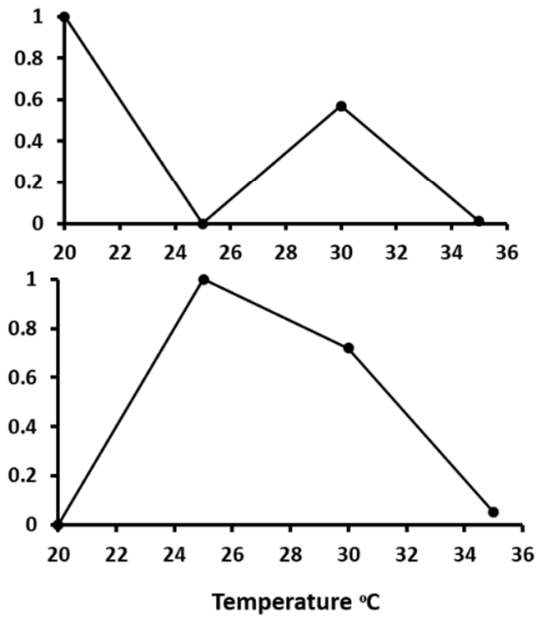

(b)

Figure 4. Growth rate, sporulation, and ochratoxin A data of A. westerdijkiae IBT 23971 before (a) and after (b) normalization in relation to temperature at $0.95 \mathrm{a}_{\mathrm{w}}$ on YES medium.
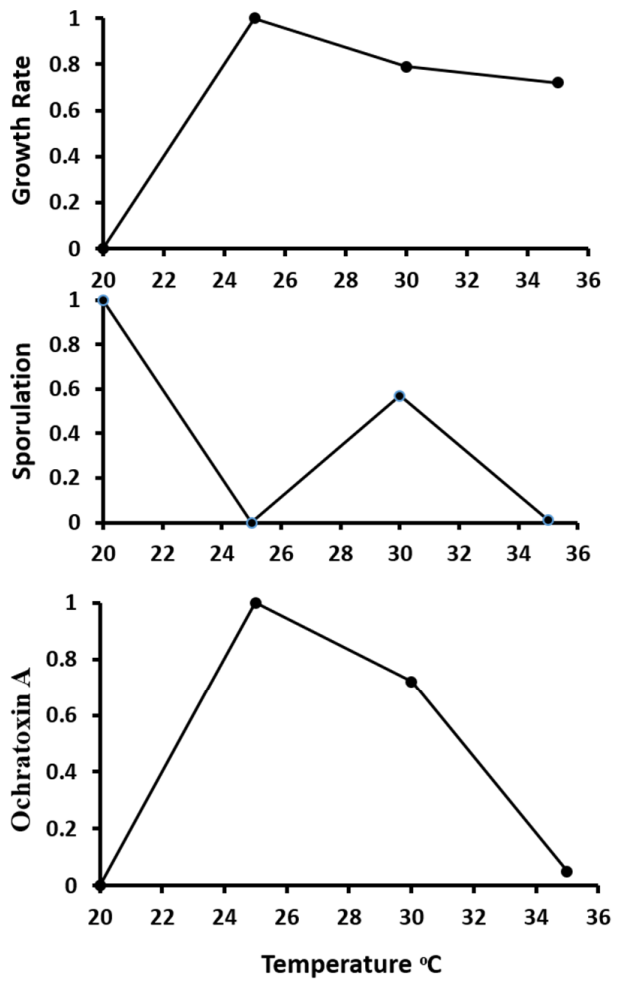

(a)
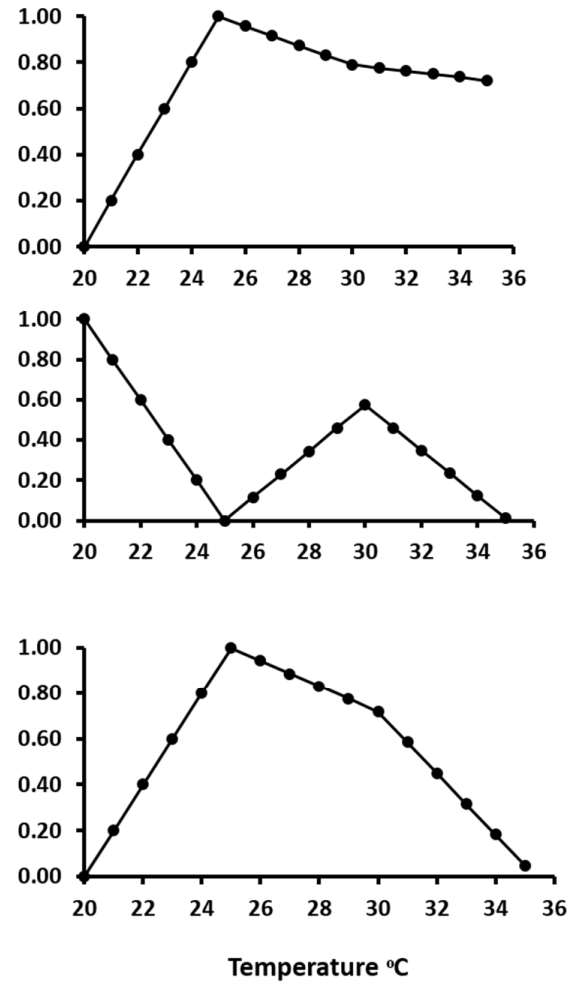

(b)

Figure 5. Growth rate, sporulation, and ochratoxin A data of A. westerdijkiae IBT 23971 before (a) and after (b) linear interpolation in relation to temperature at $0.95 \mathrm{a}_{\mathrm{w}}$ on YES medium. 

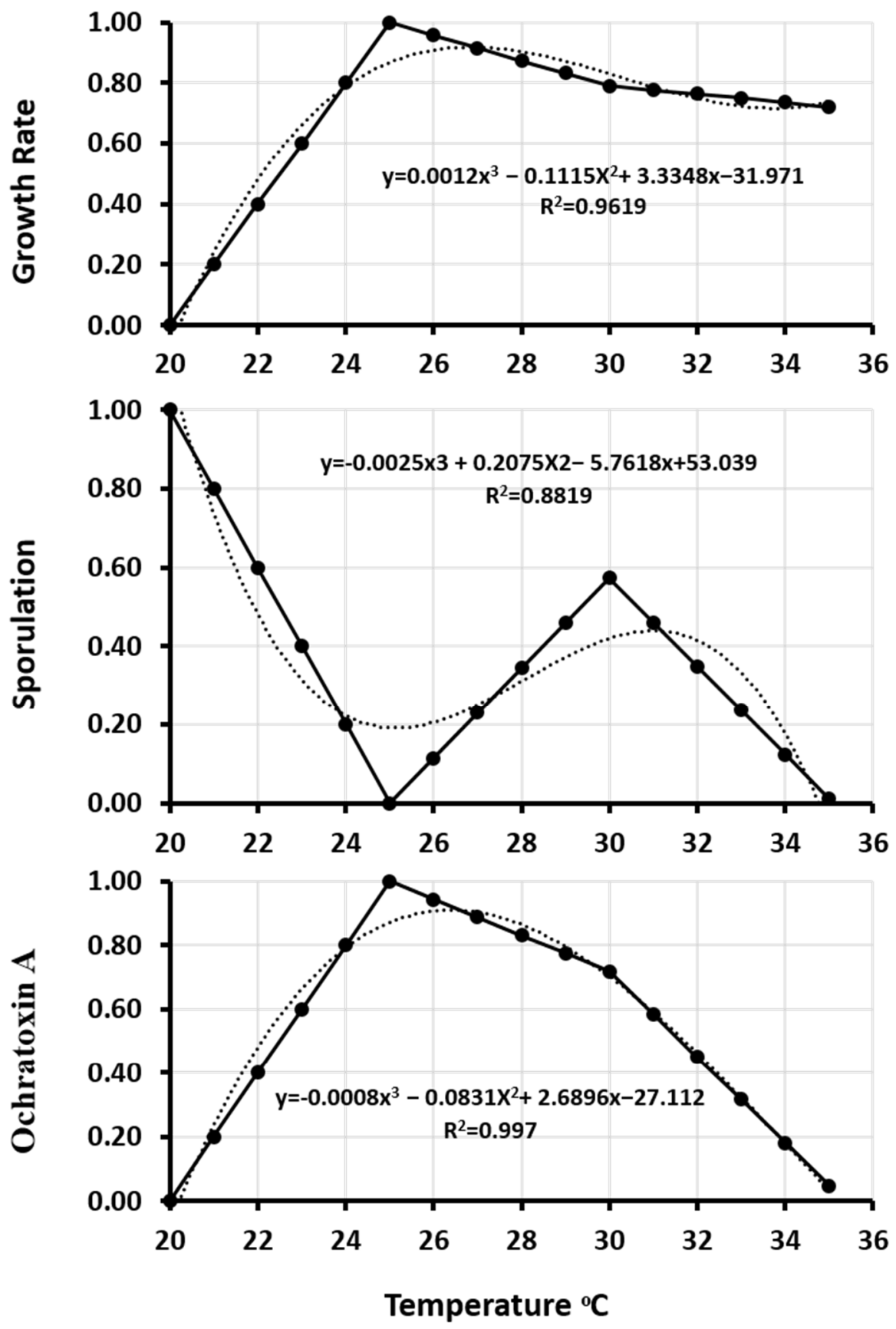

Figure 6. Multiple degree polynomial regression of growth rate, sporulation, and ochratoxin A of A. westerdijkiae IBT 23971 in relation to temperature at $0.95 \mathrm{a}_{\mathrm{w}}$ on YES medium.

The equations derived from the third-order polynomial regression model of $A$. westerdijkiae IBT 23971 were tested against $A$. steynii IBT 23096 data. The accuracy of the generated model was $96 \%$ for growth rate, $94.7 \%$ for sporulation, and $90.9 \%$ with OTA production with RMSE $0.039,0.054$, and 0.09 , respectively. The model was then validated against external data from Abdel-Hadi and Magan [13] for Aspergillus westerdijkiae 10738, Aspergillus steynii 22339, and Aspergillus ochraceus 11952 over a wide range of temperature and $0.95 \mathrm{a}_{\mathrm{W}}$. RMSE values for growth rate ranged from 0.0390 to 0.2296 , sporulation was 0.0539 to 0.5562 , and OTA was 0.0912 to 0.4332 for all tested strains (Table 3). RMSE is an indicator of residual differences between the predicted and the observed data [46]. The RMSE of an acceptable developed model for $A$. flavus growth reportedly ranged from 0.1 to 0.849 [47]. We used an effective modeling approach to examine the effects of abiotic climatic variables on 
growth, sporulation, and OTA production, where RMSE values for this study ranged from 0.0390 to 0.5562 . Another study implemented a second-order polynomial model with OTA aggregation as a variable of time, $\mathrm{a}_{\mathrm{w}}$, temperature, and carbendazim concentrations. The model recorded a reasonable coefficient of similarity between observed and expected model values, excluding higher and lower OTA amounts where predictability was harder [48]. Other studies reported that models which applied culture media performed poorly when compared to food matrices [49]. This may be due to deficiencies in the model or other factors that influence fungal responses.

Table 2. Predictive model equations based on third-order polynomial regression.

\begin{tabular}{|c|c|c|c|}
\hline Strains & & Equation & $R^{2}$ \\
\hline Aspergillus westerdijkiae 23971 & $\begin{array}{l}\text { Growth rate } \\
\text { Sporulation } \\
\text { Ochratoxin A }\end{array}$ & $\begin{array}{c}y=0.0012 x^{3}-0.1115 x^{2}+3.3348 x-31.971 \\
y=-0.0025 x^{3}+0.2075 x^{2}-5.7618 x+53.039 \\
y=0.0008 x^{3}-0.0831 x^{2}+2.6896 x-27.112\end{array}$ & $\begin{array}{c}0.9619 \\
0.8819 \\
0.977\end{array}$ \\
\hline Aspergillus westerdijkiae 10738 & $\begin{array}{l}\text { Growth rate } \\
\text { Sporulation } \\
\text { Ochratoxin A }\end{array}$ & $\begin{array}{c}y=0.0001 x^{3}-0.0227 x^{2}+0.954 x-11.222 \\
y=-0.0002 x^{3}+0.0042 x^{2}+0.3017 x+5.9932 \\
y=-0.0004 x^{3}+0.0153 x^{2}+0.0258 x-3.7228\end{array}$ & $\begin{array}{l}0.9927 \\
0.9871 \\
0.9848\end{array}$ \\
\hline Aspergillus steynii 22339 & $\begin{array}{l}\text { Growth rate } \\
\text { Sporulation } \\
\text { Ochratoxin A }\end{array}$ & $\begin{array}{c}y=0.001 x^{3}-0.0904 x^{2}+2.673 x-25.514 \\
y=-0.0009 x^{3}+0.0654 x^{2}+1.5539 x+112.197 \\
y=0.0008 x^{3}-0.0687 x^{2}+2.09792 x-20.24\end{array}$ & $\begin{array}{c}0.9797 \\
0.984 \\
0.9883\end{array}$ \\
\hline Aspergillus steynii 23096 & $\begin{array}{l}\text { Growth rate } \\
\text { Sporulation } \\
\text { Ochratoxin A }\end{array}$ & $\begin{array}{l}y=0.00003 x^{3}-0.0106 x^{2}+0.5627 x-7.321 \\
y=-0.001 x^{3}+0.0849 x^{2}-2.2961 x+19.965 \\
y=0.0004 x^{3}-0.0302 x^{2}+0.8883 x-8.5945\end{array}$ & $\begin{array}{l}0.9967 \\
0.9903 \\
0.9978\end{array}$ \\
\hline Aspergillus ochraceus 11952 & $\begin{array}{l}\text { Growth rate } \\
\text { Sporulation } \\
\text { Ochratoxin A }\end{array}$ & $\begin{array}{c}y=0.0011 x^{3}-0.0934 x^{2}+2.6015 x-23.685 \\
y=0.0013 x^{3}-0.0997 x^{2}-2.4917 x+20.127 \\
y=0.0009 x^{3}-0.062 x^{2}+1.4539 x-11.226\end{array}$ & $\begin{array}{l}0.9734 \\
0.9805 \\
0.9844\end{array}$ \\
\hline
\end{tabular}

Where $R^{2}=$ Regression coefficients.

Table 3. Model validation of Aspergillus ochraceus group.

\begin{tabular}{ccccccc}
\hline Strain & \multicolumn{2}{c}{ Growth Rate } & \multicolumn{2}{c}{ Sporulation } & \multicolumn{2}{c}{ Ochratoxin A } \\
\cline { 2 - 7 } & MSE & RMSE & MSE & RMSE & MSE & RMSE \\
\hline Aspergillus steynii 23096 & 0.0015 & 0.039 & 0.0029 & 0.0539 & 0.0083 & 0.0912 \\
Aspergillus westerdijkia 23971 & 0.0273 & 0.1654 & 0.3094 & 0.5562 & 0.1877 & 0.4332 \\
Aspergillus ochraceus 11952 & 0.0527 & 0.2296 & 0.056 & 0.2367 & 0.1516 & 0.3894 \\
Aspergillus steynii 22339 & 0.0058 & 0.0764 & 0.0832 & 0.2885 & 0.045 & 0.2123 \\
Aspergillus westerdijkia 10738 & 0.0087 & 0.0934 & 0.2217 & 0.4708 & 0.1138 & 0.3373 \\
\hline
\end{tabular}

The accuracies of the derived models for the three validated strains extracted from literature (A. westerdijkiae 10738, A. steynii 22339, and A. ochraceus 11952) reached $92.9 \%$ in growth cases, $71.7 \%$ in sporulation cases, and $78.8 \%$ in OTA production cases. All the strains showed a good similarity for both observed and predicted growth, sporulation, and OTA production at different temperatures. To show the similarity of both observed and predicted results, data of Aspergillus westerdijkiae 10738 were plotted as shown in Figure 7, while data for the other strains were not presented. In all the conditions examined, with temperature changes, a reasonable agreement was reached between the predicted and observed growth, sporulation, and OTA production with little downshift of the predicted growth and OTA production at $30^{\circ} \mathrm{C}$ and $25^{\circ} \mathrm{C}$ for sporulation. Paola et al. [26] created and assessed a computational model for functional simulation of the Aspergillus carbonarius life cycle in grapes during the growing season, along with OTA production in berries. They reported that model validation was not achievable due to poor OTA contamination results. However, there were significant differences in the model output index between lower and higher risk areas. 

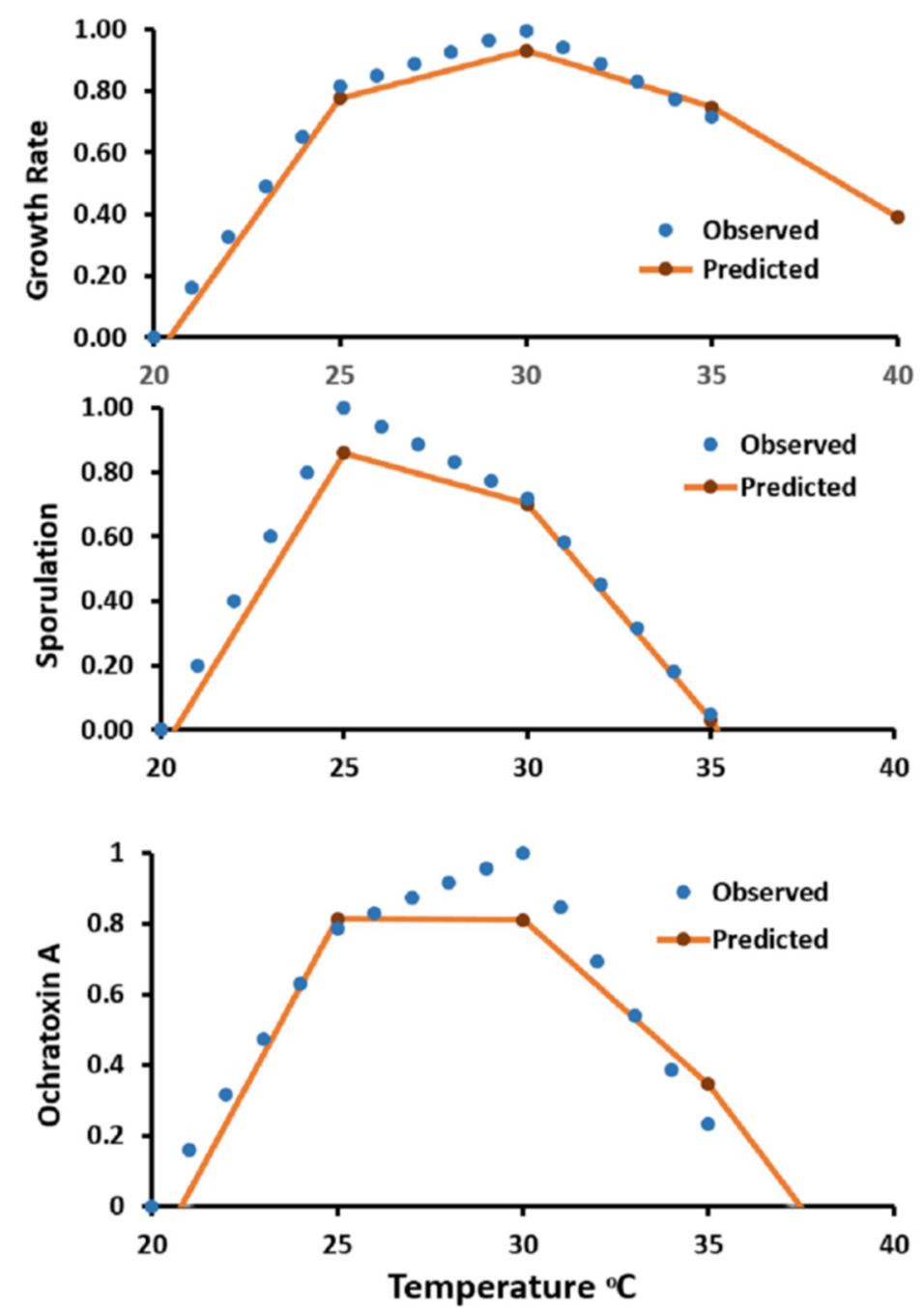

Figure 7. Comparison between observed and predicted values of growth, sporulation, and ochratoxin A of $A$. westerdijkiae IBT 10738 in relation to temperature at $0.95 \mathrm{a}_{\mathrm{w}}$ on a YES medium.

One of the most critical elements of model generation is to ensure that the model's predictions are adapted to actual scenarios. Therefore, model validation is important. It requires a comparison between model predictions and the actual observations, which should be different from the data used to create the original model [50]. External validation of existing models to describe fungal growth and mycotoxin production are scarce. Marín et al. [51] validated models for probability growth and OTA production by $A$. carbonarius related to moisture content and temperature on pistachio nuts. The authors found that the accuracy of the model was shown to predict $73-91 \%$ of growth cases, while the probability of the presence of OTA was accurately predicted in $90 \%$ of cases. Our model showed good performance when applied to three species of the Aspergillus ochraceus group on culture media. These models need to be validated on food matrices that can be contaminated with OTA producers.

\section{Conclusions}

Our findings showed that the growth rate, sporulation, and OTA production of the A. ochraceus group as a function of abiotic climatic variables (temperature and water activity) could be predicted quantitatively in other or similar environments using the developed models. Moreover, the third-order polynomial regression model approached reasonable agreement between the predicted and observed growth rates, sporulation, and OTA production, where $R^{2}$ ranged from 0.8819 to 0.9978 . The optimal abiotic climatic 
variables for growth rate, sporulation, and OTA production closely resemble previous studies. However, it is necessary to validate the models in food matrices, especially for new strains to evaluate the consequences of lapses in the process and storage conditions and estimate the degree to which abiotic climatic variables and their interactions influence storage stability and food safety without the need for a long-term storage study. By controlling abiotic climatic variables at different places in the storage unit and integrating these data into the models, it is possible to estimate if these conditions are favorable to the growth of A. ochraceus group or OTA production. Additionally, predictive models for other factors, such as $\mathrm{CO}_{2}$ level, use of fungicides, and genomic information that may have a role in OTA management, need to be investigated.

Author Contributions: A.A.-H. and B.A. designed experimental work, conducted experiments, and drafted the manuscript; M.A. (Mohammed Alaidarous), M.A. (Mohamed Awad), A.B. and M.P. contributed significantly to experimental and the analysis of the data; S.B. provided technical assistance; M.W. and M.A. (Mohammed Aboamer) created and tested the models and participated in statistical analysis of the data. All authors have read and agreed to the published version of the manuscript.

Funding: This research received no external funding.

Institutional Review Board Statement: Not applicable.

Informed Consent Statement: Not applicable.

Data Availability Statement: The data used to support the findings of this study are available from the corresponding author upon request.

Acknowledgments: The authors thank the Deanship of Scientific Research and the Deanship of Community Service at Majmaah University, Kingdom of Saudi Arabia, for supporting this work. The authors thank secondary school students (Hamoud Saad Al-Sahli, Sami Mohammed Al-Nakhilan, Ahmed Abdul Rahman Al-Nakhilan, and Osama Suliman Al-Arfaj) for participating in this work.

Conflicts of Interest: The authors declare no conflict of interest.

\section{References}

1. Duarte, S.C.; Pena, A.; Lino, C.M. A review on ochratoxin A occurrence and effects of processing of cereal and cereal derived food products. Food Microbiol. 2010, 27, 187-198. [CrossRef]

2. Pietri, A.; Rastelli, S.; Bertuzzi, T. Ochratoxin A and aflatoxins in liquorice products. Toxins 2010, 2, 758-770. [CrossRef]

3. Zaied, C.; Abid, S.; Bouaziz, C.; Chouchane, S.; Jomaa, M.; Bacha, H. Ochratoxin A levels in spices and dried nuts consumed in Tunisia. Food Addit. Contam. Part B 2010, 3, 52-57. [CrossRef]

4. Frisvad, J.C.; Frank, J.M.; Houbraken, J.A.M.P.; Kuijpers, A.F.A.; Samson, R.A. New ochratoxin A producing species of Aspergillus section circumdati. Stud. Mycol. 2004, 50, 23-43.

5. Gil-Serna, J.; Vazquez, C.; Sandino, F.G.; Valle, A.M.; Gonzalez-Jáen, M.T.; Patiño, B. Evaluation of growth and ochratoxin A production by Aspergillus steynii and Aspergillus westerdijkiae in green-coffee based medium under different environmental conditions. Food Res. Int. 2014, 61, 127-131. [CrossRef]

6. Taniwaki, M.H.; Teixeira, A.A.; Teixeira, A.R.; Copetti, M.V.; Iamanaka, B.T. Ochratoxigenic fungi and ochratoxin A in defective coffee beans. Food Res. Int. 2014, 61, 161-166. [CrossRef]

7. Leitao, A.L. Occurrence of ochratoxin A in coffee: Threads and solutions-A mini-review. Beverages 2019, 5, 36. [CrossRef]

8. Díaz, G.A.; Torres, R.; Vega, M.; Latorre, B.A. Ochratoxigenic Aspergillus species on grapes from Chilean vineyards and Aspergillus threshold levels on grapes. Int. J. Food Microbiol. 2009, 133, 195-199. [CrossRef]

9. Santos, L.; Marín, S.; Mateo, E.M.; Gil-Serna, J.; Valle-Algarra, F.M.; Patiño, B.; Ramos, A.J. Mycobiota and co-occurrence of mycotoxins in capsicum powder. Int. J. Food Microbiol. 2011, 151, 270-276. [CrossRef]

10. Mateo, E.M.; Gil-Serna, J.; Patiño, B.; Jiménez, M. Aflatoxins and ochratoxin A in stored barley grain in Spain and impact of PCR-based strategies to assess the occurrence of aflatoxigenic and ochratoxigenic Aspergillus spp. Int. J. Food Microbiol. 2011, 149, 118-126. [CrossRef]

11. Vipotnik, Z.; Rodriguez, A.; Rodrigues, P. Aspergillus westerdijkiae as a major ochratoxin A risk in dry-cured ham based-media. Int. J. Food Microbiol. 2017, 16, 244-251. [CrossRef]

12. Gil-Serna, J.; Vázquez, C.; Sardiñas, N.; González-Jaén, M.T.; Patiño, B. Revision of ochratoxin A production capacity by the main species of Aspergillus section circumdati. Aspergillus steynii revealed as the main risk of OTA contamination. Food Control 2011, 22, 343-345. [CrossRef] 
13. Abdel-Hadi, A.; Magan, N. Influence of physiological factors on growth, sporulation and ochratoxin A/B production of the new Aspergillus ochraceus grouping. World Mycotoxin J. 2009, 2, 429-434. [CrossRef]

14. Gil-Serna, J.; Patiño, B.; Cortes, L.; Gonzalez-Jaen, M.T.; Vazquez, C. Aspergillus steynii and Aspergillus westerdijkiae as potential risk of OTA contamination in food products in warm climates. Food Microbiol. 2015, 46, 168-175. [CrossRef]

15. Akbar, A. Growth and Ochratoxin A Production by Aspergillus Species in Coffee Beans: Impact of Climate Change and Control Using O3. Ph.D. Thesis, Cranfield University, Bedford, UK, 2015.

16. Akbar, A.; Medina, A.; Magan, N. Impact of climate change factors on growth and ochratoxin A production by Aspergillus sections Circumdati and Nigri species on coffee. World Mycotoxin J. 2016, 9, 863-874. [CrossRef]

17. Medina, A.; Akbar, A.; Baazeem, A.; Rodriguez, A.; Magan, N. Climate change, food security and mycotoxins: Do we know enough? Fungal Biol. Rev. 2017, 31, 143-154. [CrossRef]

18. Akbar, A.; Medina, A.; Magan, N. Resilience of Aspergillus westerdijkiae strains to interacting climate-related abiotic factors: Effects on growth and ochratoxin A production on coffee-based medium and in stored coffee. Microorganisms 2020, 8, 1268. [CrossRef]

19. Abdelmohsen, S.; Verheecke-Vaessen, C.; Garcia-Cela, E.; Medina, A.; Magan, N. Dynamics of solute/matric stress interactions with climate change abiotic factors on growth, gene expression and ochratoxin A production by Penicillium verrucosum on a wheat-based matrix. Fungal Biol. 2021, 125, 62-68. [CrossRef]

20. Baazeem, A.; Garcia-Cela, E.; Medina, A.; Magan, N. Interacting abiotic factors affect growth and aflatoxin b1 production profiles of Aspergillus flavus strains on pistachio-based matrices and pistachio nuts. Front. Microbiol. 2021, 11, 624007. [CrossRef]

21. Dantigny, P.; Guilmart, A.; Radoi, F.; Bensoussan, M.; Zwietering, M. Modelling the effect of ethanol on growth rate of food spoilage moulds. Int. J. Food Microbiol. 2005, 98, 261-269. [CrossRef]

22. Garcia, D.; Ramos, A.J.; Sanchis, V.; Marin, S. Predicting mycotoxins in foods: A review. Food Microbiol. 2009, 26, 757-769. [CrossRef]

23. Whiting, R.C. Microbial modelling in foods. Crit. Rev. Food Sci. Nut. 1995, 6, 467-494. [CrossRef]

24. Marks, B.P. Status of microbial modelling in food process models. Comp. Rev. Food Sci. Food Saf. 2007, 7, 137-143. [CrossRef]

25. Kapetanakou, A.E.; Ampavi, A.; Yanniotis, S.; Drosinos, E.H.; Skandamis, P.N. Development of a model describing the effect of temperature, water activity and (gel) structure on growth and ochratoxin A production by Aspergillus carbonarius in vitro and evaluation in food matrices of different viscosity. Food Microbiol. 2011, 28, 727-735. [CrossRef]

26. Paola, B.; Camardo, L. OTA-grapes: A mechanistic model to predict ochratoxin A risk in grapes, a step beyond the systems approach. Toxins 2015, 7, 3012-3029. [CrossRef]

27. Kaminiaris, M.D.; Camardo Leggieri, M.; Tsitsigiannis, D.I.; Battilani, P. Afla-pistachio: Development of a mechanistic model to predict the aflatoxin contamination of pistachio nuts. Toxins 2020, 12, 445. [CrossRef]

28. Gil-Serna, J.; Vazquez, C.; Patiño, B. The genomic regions that contain ochratoxin A biosynthetic genes widely differ in Aspergillus section Circumdati species. Toxins 2020, 12, 754. [CrossRef]

29. Marin, S.; Sanchis, V.; Magan, N. Water activity, temperature, and pH effects on growth of Fusarium moniliforme and Fusarium proliferatum isolates from maize. Can. J. Microbiol. 1995, 41, 1063-1070. [CrossRef]

30. Aldred, D.; Magan, N.; Lane, B.S. Influence of water activity and nutrient on growth and production of squalestatin S1 by a Phoma sp. J. Appl. Microbiol. 1999, 87, 842-848. [CrossRef]

31. Patriarca, A.; Vaamonde, G.; Fernandez, V.; Comerio, R. Influence of water activity and temperature on the growth of Wallemia sebi: Application of a predictive model. Int. J. Food Microbiol. 2001, 68, 61-67. [CrossRef]

32. Levine, D.M.; Stephan, D.; Szabat, K.A. Statistics for Managers Using Microsoft Excel, 8th ed.; 2017; Available online: http: / /elibrary.gci.edu.np/handle/123456789/813 (accessed on 6 April 2021).

33. Motulsky, H. Essential Biostatistics: A Nonmathematical Approach; Oxford University Press: New York, NY, USA, 2016.

34. Ross, T. Indices for performance evaluation of predictive models in food microbiology. J. Appl. Microbiol. 1996, 81, 501-508. [CrossRef]

35. Wawrzyniak, J.; Ryniecki, A.; Gawrysiak-Witulska, M. Kinetics of mould growth in the stored barley ecosystem contaminated with Aspergillus westerdijkiae, Penicillium viridicatum and Fusarium poae at 23-30 ${ }^{\circ}$ C. J. Sci. Food Agric. 2013, 93, 895-901. [CrossRef]

36. European Commission. Adapting to Climate Change in Europe-Options for EU Action; Green paper from the Commission to the Council, the European Parliament, the European Economic and Social Committee of the Regions, SEC 849, COM 354 Final; European Commission: Brussels, Belgium, 2007.

37. Parra, R.; Aldred, D.; Archer, D.; Magan, N. Water activity, solute and temperature modify growth and spore production of wild type and genetically engineered Aspergillus niger strains. Enzyme Microb. Technol. 2004, 35, 232-237. [CrossRef]

38. Kapetanakou, A.E.; Panagou, E.Z.; Gialitaki, M.; Drosinos, E.H.; Skandamis, P.N. Evaluating the combined effect of water activity, $\mathrm{pH}$ and temperature on ochratoxin A production by Aspergillus ochraceus and Aspergillus carbonarius on culture medium and corinth raisins. Food Control 2009, 20, 725-732. [CrossRef]

39. Rossi, V.; Scandolara, A.; Battilani, P. Effect of environmental conditions on spore production by Fusarium verticillioides, the causal agent of maize ear rot. Europ. J. Plant Pathol. 2009, 123, 159-169. [CrossRef]

40. Giorni, P.; Camardo Leggieri, M.; Magan, N.; Battilani, P. Comparison of ecological needs for sporulation of Aspergillus flavus sclerotia on natural and artificial substrates. Fungal Biol. 2012, 116, 637-642. [CrossRef] [PubMed]

41. Zhang, F.; Guo, Z.; Zhong, H.; Wang, S.; Yang, W.; Liu, Y.; Wang, S. RNA-Seq-based transcriptome analysis of aflatoxigenic Aspergillus flavus in response to water activity. Toxins 2014, 6, 3187-3207. [CrossRef] [PubMed] 
42. Lappa, I.K.; Kizis, D.; Panagou, E.Z. Monitoring the temporal expression of genes involved in ochratoxin A production of Aspergillus carbonarius under the influence of temperature and water activity. Toxins 2017, 9, 296. [CrossRef]

43. Cervini, C.; Gallo, A.; Piemontese, L.; Magistà, D.; Logrieco, A.F.; Ferrara, M.; Solfrizzo, M.; Perrone, G. Effects of temperature and water activity change on ecophysiology of ochratoxigenic Aspergillus carbonarius in field-simulating conditions. Int. J. Food Microbiol. 2020, 315, 108420. [CrossRef] [PubMed]

44. Perrone, G.; Ferrara, M.; Medina, A.; Pascale, M.; Magan, N. Toxigenic fungi and mycotoxins in a climate change scenario: Ecology, genomics, distribution, prediction and prevention of the risk. Microorganisms 2020, 8, 1496. [CrossRef]

45. Dantigny, P.; Bensoussan, M. The logarithmic transformation should be avoided for stabilising the variance of mould growth rate. Int. J. Food Microbiol. 2008, 121, 225-228. [CrossRef]

46. Marin, S.; Ramos, A.J.; Sanchis, V. Modelling Aspergillus flavus growth and aflatoxins production in pistachio nuts. Food Microbiol. 2012, 32, 378-388. [CrossRef] [PubMed]

47. Marin, S.; Colom, C.; Sanchis, V.; Ramos, A.J. Modelling of growth of aflatoxigenic A. flavus isolates from red chili powder as a function of water availability. Int. J. Food Microbiol. 2009, 128, 491-496. [CrossRef]

48. Medina, A.; Mateo, R.; Valle-Algarra, F.M.; Mateo, E.M.; Misericordia, J. Effect of carbendazim and physicochemical factors on the growth and ochratoxin A production of Aspergillus carbonarius isolated from grapes. Int. J. Food Microbiol. 2007, 119, 230-235. [CrossRef] [PubMed]

49. Garcia, D.; Ramos, A.J.; Sanchis, V.; Marin, S. Modeling kinetics of aflatoxin production by Aspergillus flavus in maize-based medium and maize grain. Int. J Food Microbiol. 2013, 162, 182-189. [CrossRef] [PubMed]

50. Brocklehurst, T. Challenge of food and the environment. In Modelling Microbial Responses in Food; McKellar, R.C., Lu, X., Eds.; CRC Press: Boca Raton, FL, USA, 2004; pp. 197-232.

51. Marín, S.; Hodzic, I.; Ramos, A.J.; Sanchis, V. Predicting the growth/no growth boundary and ochratoxin A production by Aspergillus carbonarius in pistachio nuts. Food Microbiol. 2008, 25, 683-689. [CrossRef] [PubMed] 